THE POLITICS OF PREJUDICE 



\section{THE POLITICS OF PREJUDICE}

The Anti-Japanese Movement in California and the Struggle for Japanese Exclusion

ROGER DANIELS

UNIVERSITY OF CALIFORNIA PRESS

Berkeley $\cdot$ Los Angeles - London 
UNIVERSITY OF CALIFORNIA PRESS

BERKELEY AND LOS ANGELES. CALIFORNIA

UNIVERSITY OF CALIFORNIA PRESS. ITD.

LONDON, ENGIAND

COPYRIGHT O 1962 BY THE REGENTS OF THE UNIVERSITY OF CALIFORNIA AI.I. RICHTS RESERVED,

FIRST CALIFORNIA PAPERBACK EDITION. 1977 CALIFORNIA LIBRARY REPRINTS SERIES EDITION. 1977 ISBN: 0-520-21950-3 (PAPER)

PRINTED IN THE, UNITED STATES OF AMERICA

$\begin{array}{lllllllll}1 & 2 & 3 & 4 & 5 & 6 & 7 & 8 & 9\end{array}$

The paper used in this publication is both acid-free and totally chlorine-free (TCF). It meets the minimum requirements of American Standard for Information SriencesPermanence of Paper for Printed Library Materials. ANSI Z39.48-1984. () 